University of Wollongong

Research Online

Australian Institute for Innovative Materials -

Papers

Australian Institute for Innovative Materials

$1-1-2013$

\title{
Co304 nanorods decorated reduced graphene oxide composite for oxygen reduction reaction in alkaline electrolyte
}

\author{
Mingyan Wang \\ University of Wollongong, mingyan@uow.edu.au \\ Junrao Huang \\ Huaihai Institute of Technology \\ Meng Wang \\ University of Wollongong, mw088@uowmail.edu.au \\ Dongen Zhang \\ Huaihai Institute of Technology \\ Weimin Zhang \\ University Of Wollongong, weimin@uow.edu.au
}

See next page for additional authors

Follow this and additional works at: https://ro.uow.edu.au/aiimpapers

Part of the Engineering Commons, and the Physical Sciences and Mathematics Commons

\footnotetext{
Research Online is the open access institutional repository for the University of Wollongong. For further information
} contact the UOW Library: research-pubs@uow.edu.au 


\title{
Co304 nanorods decorated reduced graphene oxide composite for oxygen reduction reaction in alkaline electrolyte
}

\author{
Abstract \\ Highly uniform $\mathrm{Co} 304$ nanorods decorated on reduced graphene oxide ( $\mathrm{rGO}$ ) were prepared by a one-pot \\ hydrothermal procedure. During the hydrothermal process, Co2+ ions were crystallized to Co3O4 \\ nanorods and simultaneously GO was reduced to rGO to form the Co304/rGO hybrid. The Co304/rGO \\ hybrid was characterized by scanning electron micrographs, X-ray diffraction, X-ray photoelectron \\ spectroscopy, and Raman spectroscopy. The obtained Co304/rGO hybrid exhibits excellent \\ electrocatalytic performance for oxygen reduction reaction.

\section{Keywords} \\ co3o4, nanorods, electrolyte, reaction, alkaline, decorated, reduced, composite, graphene, reduction, oxide, \\ oxygen \\ Disciplines \\ Engineering | Physical Sciences and Mathematics

\section{Publication Details} \\ Wang, M., Huang, J., Wang, M., Zhang, D., Zhang, W., Li, W. and Chen, J. (2013). Co304 nanorods \\ decorated reduced graphene oxide composite for oxygen reduction reaction in alkaline electrolyte. \\ Electrochemistry Communications, 34 (September), 299-303.

\section{Authors} \\ Mingyan Wang, Junrao Huang, Meng Wang, Dongen Zhang, Weimin Zhang, Weihua Li, and Jun Chen
}


$1 \mathrm{Co}_{3} \mathrm{O}_{4}$ nanorods decorated reduced graphite oxide composite for oxygen

2 reduction reaction in alkaline electrolyte

3 Mingyan Wang a,b, Junrao Huang ${ }^{a}$, Meng Wang ${ }^{b}$, Dongen Zhang ${ }^{a}$, Weimin Zhang, Weihua $\mathrm{Li}^{\mathrm{c}}$, Jun Chen ${ }^{\mathrm{b} *}$

${ }^{a}$ Department of Chemical Engineering, Huaihai Institute of Technology. Lianyungang, 222005, China

${ }^{b}$ Intelligent Polymer Research Institute, ARC Centre of Excellence for Electromaterials Science, Australian Institute of Innovative Materials, University of Wollongong, Northfields Avenue, Wollongong, NSW 2522, Australia ${ }^{c}$ School of Mechanical, Materials \& Mechatronic Engineering, University of Wollongong, Northfields Avenue, Wollongong, NSW 2522, Australia

13 The contact details of corresponding authors:

14 Jun Chen: Phone: +61-2-42213781; fax: +61-2-4221 3114; junc@uow.edu.au. 


\section{Abstract}

2 Highly uniform $\mathrm{Co}_{3} \mathrm{O}_{4}$ nanorods decorated on reduced graphene oxide (rGO) were 3 prepared by a one-pot hydrothermal procedure. During the hydrothermal process,

$4 \mathrm{Co}^{2+}$ ions were crystallized to $\mathrm{Co}_{3} \mathrm{O}_{4}$ nanorods and simultaneously $\mathrm{GO}$ was reduced to 5 rGO to form the $\mathrm{Co}_{3} \mathrm{O}_{4} / \mathrm{rGO}$ hybrid. The $\mathrm{Co}_{3} \mathrm{O}_{4} / \mathrm{rGO}$ hybrid was characterized by 6 scanning electron micrographs, X-ray diffraction, X-ray photoelectron spectroscopy,

7 and Raman spectroscopy. The obtained $\mathrm{Co}_{3} \mathrm{O}_{4} / \mathrm{rGO}$ hybrid exhibits excellent 8 electrocatalytic performance for oxygen reduction reaction.

9 Keywords: $\mathrm{Co}_{3} \mathrm{O}_{4}$ nanorods; reduced graphene oxide; oxygen reduction reaction 


\section{Introduction}

The cathodic oxygen reduction reaction (ORR) is one of the key challenges in developing alkaline-based fuel cells and metal-air batteries [1]. Recently, transition metal oxides [2-5].as promising cathodic materials, have received considerable attention due to their high catalytic activity, low cost and environmental friendliness. However, these materials also suffer from some disadvantages, such as relatively poor electrical conductivity and lower electron transfer rate, which limited their applications in real devices. It is well known that graphene exhibits notable electronic conductivity and high surface area, which could be an attractive support for metal oxides to form a new class of nanocomposites for ORR. [6-8] Dai's group [9-11] reported a series of nanocomposites consisting of $\mathrm{Co}_{3} \mathrm{O}_{4}, \mathrm{Mn}_{3} \mathrm{O}_{4}, \mathrm{MnCo}_{2} \mathrm{O}_{4}$ nanocrystals deposited on rGO templates as excellent catalysts for ORR. However, it is still a challenge to develop a simple facile deposition approach to prepare quality metal oxide/rGO catalysts for ORR with stable performance. To the best of our knowledge, the fabrication of $\mathrm{Co}_{3} \mathrm{O}_{4}$ nanorods decorated on rGO supports for ORR has not yet been reported.

In this work, we report a facile route to prepare $\mathrm{Co}_{3} \mathrm{O}_{4}$ nanorods decorated $\mathrm{rGO}$ hybrid through a one-pot hydrothermal approach showing an efficient pathway for charge transfer. The as-prepared $\mathrm{Co}_{3} \mathrm{O}_{4} / \mathrm{rGO}$ exhibits a significant enhancement in electrocatalytic ORR performance in alkaline media, compared with unsupported $\mathrm{Co}_{3} \mathrm{O}_{4}$ or pure reduced graphene oxide. 


\section{Experimental}

\subsection{Synthesis of $\mathrm{Co}_{3} \mathrm{O}_{4} / \mathrm{rGO}$ nanocomposite}

Graphene oxide (GO) was synthesized by the modified Hummers method [12]. The $\mathrm{Co}_{3} \mathrm{O}_{4}$ modified $\mathrm{rGO}$ was synthesized as the following procedures. Firstly, 2 mmol $\mathrm{Co}(\mathrm{Ac})_{2} \cdot 4 \mathrm{H}_{2} \mathrm{O}$ and $2 \mathrm{mmol} \mathrm{CO}\left(\mathrm{NH}_{2}\right)_{2}$ as a stabilizer were dissolved into $30 \mathrm{~mL}$ distilled water. Then, GO powders (with various mass weights) were added into the above solution and sonicated for $1 \mathrm{~h}$, followed with an addition of $1 \mathrm{~mL} 6 \%$ hydrogen peroxide as an oxidizer and magnetically stirred for $6 \mathrm{~h}$ at room temperature. The as-prepared solution was then transferred into a Teflon liner, which was sealed in a steel autoclave. The autoclave was maintained at $190{ }^{\circ} \mathrm{C}$ for $5 \mathrm{~h}$ and then was allowed to cool down to room temperature by a cool-water system. The resulting precipitate was separated by filtration, and washed with distilled water and absolute ethanol for 5 times. Final black-color $\mathrm{Co}_{3} \mathrm{O}_{4} / \mathrm{rGO}$ powders were achieved via vacuum-dry in a vacuum oven at $60{ }^{\circ} \mathrm{C}$ for $5 \mathrm{~h}$. For comparison pure $\mathrm{Co}_{3} \mathrm{O}_{4}$ powder without $\mathrm{rGO}$ and rGO without $\mathrm{Co}_{3} \mathrm{O}_{4}$ were also prepared under identical conditions.

\subsection{Physical characterization}

The crystalline properties and morphologies of the as-prepared materials were characterized by powder X-ray diffraction (XRD, D8-advanced, Bruker, $40 \mathrm{kV}, 20 \mathrm{~mA}$, $\mathrm{Cu} \mathrm{K} \alpha$ radiation) and scanning electron microspcopy (SEM, JEOL, JSM6700F). The atomic composition of $\mathrm{Co}_{3} \mathrm{O}_{4} / \mathrm{rGO}$ was detected by X-ray photoelectron spectroscopy (XPS, Perkin Elmer, Al K $\alpha$ radiation). Raman spectroscopy was performed using a Jobin-Yvon Lab Ram HR800 system. 


\subsection{Electrochemical measurement}

Electrochemical measurements were performed using a glassy carbon rotating ring disk electrode (RRDE, Pine Research Instrumentation), connected to a $\mathrm{CHI} 720 \mathrm{c}$ potentiostat in a standard three-electrode cell with a platinum wire as the counter electrode and a $3 \mathrm{M} \mathrm{KCl}$ saturated $\mathrm{Ag} / \mathrm{AgCl}$ electrode as the reference electrode. Electrochemical impedance spectroscopy (EIS) measurement was carried out at open circuit potential with an ac perturbation of $5 \mathrm{mV}$ in the frequency range from $0.01 \mathrm{~Hz}$ to $100 \mathrm{kHz}$ using a Solartron SI1260 Impedance Analyzer. The catalyst loading on the electrode was maintained as $80 \mu \mathrm{g} \mathrm{cm}^{-2}$ for all the electrochemical testing.

\section{Results and Discussion}

The fabrication process is illustrated in Figure 1a. Firstly, $\mathrm{Co}^{2+}$ ion was easily coordinated with negatively charged oxygen-containing functional groups on GO sheets. Followed by the hydrothermal process, $\mathrm{Co}^{2+}$ was oxidized into $\mathrm{Co}^{3+}$ by the oxygen-containing functional groups on the GO surface. The oxidized $\mathrm{Co}^{3+}$ and $\mathrm{Co}^{2+}$ coprecipitated into $\mathrm{Co}_{3} \mathrm{O}_{4}$, the resultant $\mathrm{Co}_{3} \mathrm{O}_{4}$ nanorods were in-situ grown on the rGO (in-situ thermal reduced from GO as support templates), similar to the formation of rGO sheets decorated with nanoparticles, as reported previously [7, 13]. Scanning electron microscopy (SEM) was employed to investigate the morphologies of $\mathrm{Co}_{3} \mathrm{O}_{4} / \mathrm{rGO}$ samples as shown in Figure $1 \mathrm{~b}$. It has been clearly shown that the $\mathrm{Co}_{3} \mathrm{O}_{4}$ nanorods were uniformly deposited onto the rGO substrate with an average length of $\sim 200 \mathrm{~nm}$ and a diameter around $20 \mathrm{~nm}$. Energy dispersive spectroscopy (EDS) 
1 analysis given in Figure 1c indicates the existence of Co, O and $\mathrm{C}$. The atomic ratio

2 of $\mathrm{Co}$ to $\mathrm{O}$ is $3: 4$ which is in complete accord with the stoichiometry of $\mathrm{Co}_{3} \mathrm{O}_{4}$. Si

3 signal aroused from the Si substrate. XRD was performed to investigate the phase structure of $\mathrm{GO}$, pristine $\mathrm{Co}_{3} \mathrm{O}_{4}$ and

$5 \mathrm{Co}_{3} \mathrm{O}_{4} / \mathrm{rGO}$. The as-synthesized GO displayed a typical characteristic (002) peak at

$6 \quad 10.1^{\mathrm{o}}$ (Figure 2a). Then after the hydrothermal process, the as-prepared rGO showed a 7 broad (002) peak at $2 \theta$ of $24.2^{\circ}$, corresponding to the d-spacing of $0.36 \mathrm{~nm}$, and the 8 strong (002) peak centred at $10.1^{\circ}$ disappeared, indicating that GO has been reduced to rGO. [14]. The diffraction peaks of the pristine $\mathrm{Co}_{3} \mathrm{O}_{4}$ are in good agreement with the standard $\mathrm{Co}_{3} \mathrm{O}_{4}$ (JCPDS card: 42-1467) [15]. The major diffraction peaks of $\mathrm{Co}_{3} \mathrm{O}_{4} / \mathrm{rGO}$ were well indexed with those of $\mathrm{Co}_{3} \mathrm{O}_{4}$ except for the broad (002) peak at approximately $25^{\circ}$, which can be attributed to disordered stacked graphitic sheets [16]. This clearly demonstrates that the original GO has been reduced to rGO during the hydrothermal process. The phases of $\mathrm{Co}_{3} \mathrm{O}_{4}$ and $\mathrm{rGO}$ were further confirmed by Raman spectroscopy. The typical Raman spectra of $\mathrm{GO}, \mathrm{rGO}$ and $\mathrm{Co}_{3} \mathrm{O}_{4} / \mathrm{rGO}$ are shown in Figure $2 \mathrm{~b}$, where the peaks of Raman spectrum of $\mathrm{Co}_{3} \mathrm{O}_{4} / \mathrm{rGO}$ at 193,470 , 520,615 and $680 \mathrm{~cm}^{-1}$, can be attributed to the $\mathrm{E}_{\mathrm{g}}, \mathrm{F}_{2 \mathrm{~g}}$ and $\mathrm{A}_{1 \mathrm{~g}}$ modes of $\mathrm{Co}_{3} \mathrm{O}_{4}$ [16]. It is noted that $\mathrm{GO}$ exhibits a $\mathrm{G}$ band at $1606 \mathrm{~cm}^{-1}$, while the corresponding $\mathrm{G}$ bands of rGO and $\mathrm{Co}_{3} \mathrm{O}_{4} / \mathrm{rGO}$ are 1586 and $1589 \mathrm{~cm}^{-1}$, respectively. The red shifts of $\mathrm{G}$ band of rGO and $\mathrm{Co}_{3} \mathrm{O}_{4} / \mathrm{rGO}$ can be attributed to the high ability for recovery of the hexagonal network of carbon [17], which is consistent with the decrease of the $D / G$ ratio. 

$2 \mathrm{c}$ correspond to the characteristic peaks of $\mathrm{C} 1 \mathrm{~s}, \mathrm{O} 1 \mathrm{~s}$ and $\mathrm{Co} 2 \mathrm{p}$, indicating the

3 existence of carbon, oxygen and cobalt elements in the sample. The XPS spectrum for

4 Co2p shown in Figure 2d exhibits two major peaks with binding energies at 780.1 and $5797.1 \mathrm{eV}$, corresponding to $\mathrm{Co} 2 \mathrm{p}_{3 / 2}$ and $\mathrm{Co} 2 \mathrm{p}_{1 / 2}$, respectively, with a spin-energy separation of $17 \mathrm{eV}$, which is the characteristic of a $\mathrm{Co}_{3} \mathrm{O}_{4}$ phase [18]. The $\mathrm{C} 1 \mathrm{~s}$ XPS

7 spectrum of GO (Figure 2e) could be deconvoluted into four peaks arising from $\mathrm{C}-\mathrm{C} / \mathrm{C}=\mathrm{C}(284.6 \mathrm{eV})$ in the aromatic rings, $\mathrm{C}-\mathrm{O}(286.4 \mathrm{eV})$ of epoxy and alkoxy, $\mathrm{C}=\mathrm{O}$ $(287.8 \mathrm{eV})$ and $\mathrm{O}-\mathrm{C}=\mathrm{O}(289.3 \mathrm{eV})$ groups, respectively [19]. For $\mathrm{Co}_{3} \mathrm{O}_{4} / \mathrm{rGO}$ (Figure 2f), the intensity of the oxygenated groups decreases significantly, indicating that GO

11 was reduced to rGO during the hydrothermal process [13]. This result is in a good agreement with the results of Raman spectroscopy. linear portion corresponding to a charge transfer and mass transfer process are quite 
1 diameter of the semicircle for $\mathrm{Co}_{3} \mathrm{O}_{4} / \mathrm{rGO}$ is significantly smaller than that of $\mathrm{Co}_{3} \mathrm{O}_{4}$

2 and almost similar to that of rGO. This indicates that rGO supporting materials

3 significantly enhance the electron transfer in $\mathrm{Co}_{3} \mathrm{O}_{4} / \mathrm{rGO}$, which could promote the

4 catalytic ORR much easier and more efficiently than $\mathrm{Co}_{3} \mathrm{O}_{4}$ without $\mathrm{rGO}$ supports.

The transferred electron number was studied using rotating-disk electrode (RDE) measurements (Figure 3c) according to the following Koutecky-Levich equation:

$$
\frac{1}{J}=\frac{1}{0.62 n \mathrm{~F} C_{0} D^{2 / 3} v^{-1 / 6} \omega^{1 / 2}}+\frac{1}{n \mathrm{~F} k C_{0}}
$$

where $\omega$ is the angular velocity, $n$ is the number of electrons transferred, $\mathrm{F}$ is solution and $k$ is the apparent electron transfer rate constant.

The parallel fitting lines of the Koutecky-Levich plots (insert of Figure 3c) at different potentials suggest first-order reaction kinetics toward the concentration of dissolved oxygen and similar electron transfer numbers for ORR [21]. The number of electrons transferred in ORR was calculated to be 3.50, indicating that $\mathrm{Co}_{3} \mathrm{O}_{4} / \mathrm{rGO}$ favors a 4 electron oxygen reduction process. In other words, $\mathrm{O}_{2}$ can be dominantly reduced to the final hydroxyl ion at these potentials. The almost same $n$ value (3.52) is derived from the result of the RRDE test carried out at $1600 \mathrm{rpm}$. The measured $\mathrm{H}_{2} \mathrm{O}_{2}$ yields for $\mathrm{Co}_{3} \mathrm{O}_{4} / \mathrm{rGO}$ catalyst are below $25 \%$ over the potential range of -0.3 to $-0.6 \mathrm{~V}$, suggesting the high efficiency of the ORR on $\mathrm{Co}_{3} \mathrm{O}_{4} / \mathrm{rGO}$ [21]. Furthermore, the chronoamperometric curves for catalytic ORR were recorded to study the durability of the $\mathrm{Co}_{3} \mathrm{O}_{4} / \mathrm{rGO}$ at $-0.55 \mathrm{~V}$. The $\mathrm{Co}_{3} \mathrm{O}_{4} / \mathrm{rGO}$ catalyst shows stable ORR performance 
1 after $6000 \mathrm{~s}$ of operation. While commercial $\mathrm{Pt} / \mathrm{C}$ reveals a slight degradation after

$22000 \mathrm{~s}$ of operation. This again confirms that the $\mathrm{Co}_{3} \mathrm{O}_{4} / \mathrm{rGO}$ nanocomposite has a

3 superior activity and stability for catalytic oxygen reduction in the $0.1 \mathrm{M} \mathrm{KOH}$.

4 Through the preliminary study of the mass ratios of $\mathrm{Co}_{3} \mathrm{O}_{4}$ to $\mathrm{rGO}$, it demonstrated

5 that the best catalytic performance was achieved from $\mathrm{Co}_{3} \mathrm{O}_{4} / \mathrm{rGO}$ with a mass ratio of

$6 \quad 2.6$

7

8

\section{Conclusion}

Heterogeneous $\mathrm{Co}_{3} \mathrm{O}_{4} / \mathrm{rGO}$ was synthesized by a simple one pot hydrothermal method. This method leads to a uniform distribution of $\mathrm{Co}_{3} \mathrm{O}_{4}$ nanorods on $\mathrm{rGO}$ sheets. The $\mathrm{Co}_{3} \mathrm{O}_{4} / \mathrm{rGO}$ hybrid exhibits higher catalytic activity and durability for ORR than the unsupported $\mathrm{Co}_{3} \mathrm{O}_{4}$, which present this material an efficient, low cost cathodic catalyst for alkaline-based fuel cells and metal-air batteries.

\section{Acknowledgements}

This work was supported by National Natural Science Foundation of China (Grant No. 51202079 and 21201070). The authors are also grateful to National College Student's Innovation Project and the young teachers of Jiangsu Province universities" "blue and green blue project".

\section{References}

[1]Y. Ye, L. Kuai, B. Geng, J. Mater. Chem. 22 (2012) 19132.

[2]Y. Wang, H. Xia, L. Lu, J. Lin, ACS Nano 4 (2010) 1425.

[3]S. W. Kim, H. W. Lee, P. Muralidharan, D. H. Seo, W. S. Yoon, D. K. Kim, K. Kang, Nano Res, 4 (2011) 505. 
[4]J. P. Liu, Y. Y. Li, H. J. Fan, Z. H. Zhu, J. Jiang, R. M. Ding, Y. Y. Hu, X. T. Huang, Chem Mater 22 (2010) 212.

[5]X. H. Wang, Z. B. Yang, X. L. Sun, X. W. Li, D. S. Wang, P. Wang, D. Y. He, J. Mater. Chem. 21 (2011) 9988.

[6]J. S. Lee, T. Lee, H. K. Song, J. Cho. B. S. Kim, Energy Environ. Sci. 4 (2011) 4148.

[7]X. Y. Yan, X. L. Tong, Y. F. Zhang, X. D. Han, Y. Y. Wang, G. Q. Jin, Y. Qin, X. Y. Guo, Chem. Commun. 48 (2012) 1892.

[8]Y. Qian, S. B. Lu, F. L. Gao, Mater. Lett. 65 (2011) 56.

[9]Y. Y. Liang, Y. G. Li, H. L. Wang, J. G. Zhou, J. Wang, T. Regier, H. J. Dai, Nat. mater. 10 (2011) 780.

[10]J. Feng, Y. Liang, H. Wang, Y. Li, B. Zhang, J. Zhou, J. Wang, T. Regier, H. Dai, Nano Res. 5 (2012) 718.

[11]Y. Y. Liang, H. L. Wang, J. G. Zhou, Y. G. Li, J. Wang, T. Regier, H. J. Dai, J. Am. Chem. Soc. 134 (2012) 3517.

[12]W. S. Hummers, R. E. Offeman, J. Am. Chem. Soc. 80 (1958) 1339.

[13]H. Cong, X. Ren, P. Wang, S. Yu, ACS Nano 6 (2012) 2693.

[14]S. Liu, Z. Chen, N. Zhang, Z. Tang, Y. Xu, J Phys. Chem. C. 117 (2013) 8251.

[15]L. Wang, B. Liu, S. Ran, H. Huang, X. Wang, B. Liang, D. Chen, G. Shen, J. Mater. Chem. 22 (2012) 23541.

[16]H. Kim, D. H. Seo, S. W. Kim, J. Kim, K. Kang, Carbon 49 (2011) 326.

[17]D. Kang, J. Y. Kwon, H. Cho, J. Sim, H. S. Hwang, C. S. Kim, Y. J. Kim, R. S. Ruoff, H. S. Shin, ACS Nano 6 (2012) 7763.

[18]D. Ye, L. Luo, Y. Ding, B. Liu, X. Liu, Analyst 137 (2012) 2840.

[19]O. Akhavan, M. Choobtashani, E. Ghaderi, J. Phys. Chem. C 116 (2012) 9653.

[20]I. Kruusenberg, J. Mondal, L. Matisen, V. Sammelselg, K. Tammeveski, Electrochem. Commun. 33 (2013) 18.

[21]M. Wang, W. Zhang, J. Wang, A. Minett, V. Lo, H. Liu, J. Chen, J Mater. Chem. A 1 (2013) 2391. 


\section{Figures captions}

2 Figure 1. A schematic for preparation of $\mathrm{Co}_{3} \mathrm{O}_{4} / \mathrm{rGO}$ hybrid (a); SEM image (b) and EDS spectrum (c) of the $\mathrm{Co}_{3} \mathrm{O}_{4} / \mathrm{rGO}$.

4

Figure 2. (a) XRD patters of $\mathrm{GO}, \mathrm{rGO}, \mathrm{Co}_{3} \mathrm{O}_{4}$ and $\mathrm{Co}_{3} \mathrm{O}_{4} / \mathrm{rGO}$. (b) Raman spectra of $\mathrm{GO}, \mathrm{rGO}$ and $\mathrm{Co}_{3} \mathrm{O}_{4} / \mathrm{rGO}$. (c) XPS survey spectra of $\mathrm{Co}_{3} \mathrm{O}_{4} / \mathrm{rGO}$. (d) Co2p XPS of $\mathrm{Co}_{3} \mathrm{O}_{4} / \mathrm{rGO}$ (insert: O1s), (e, f) C1s XPS for $\mathrm{GO}$ and $\mathrm{Co}_{3} \mathrm{O}_{4} / \mathrm{rGO}$.

Figure 3. (a) LSV curves of $\mathrm{Co}_{3} \mathrm{O}_{4}, \mathrm{rGO}, \mathrm{Co}_{3} \mathrm{O}_{4} / \mathrm{rGO}$ and $\mathrm{Pt} / \mathrm{C}$ in $0.1 \mathrm{M} \mathrm{KOH} \mathrm{O}_{2}$ saturated solution with rotation speed at $400 \mathrm{rpm}$ (dashed line: LSV curve of $\mathrm{Co}_{3} \mathrm{O}_{4} / \mathrm{rGO}$ in $0.1 \mathrm{M} \mathrm{KOH} \mathrm{N}$ saturated solution). (b) Nyquist plots of $\mathrm{Co}_{3} \mathrm{O}_{4}, \mathrm{rGO}$ and $\mathrm{Co}_{3} \mathrm{O}_{4} / \mathrm{rGO}$ at open potential. (c) LSV curves for $\mathrm{Co}_{3} \mathrm{O}_{4} / \mathrm{rGO}$ at various rotation speed. Insert: Koutecky-Levich plots (according to Fig 3c) at different electrode potentials. (d) Chronoamperometric curves for $\mathrm{O}_{2}$ reduction on the $\mathrm{Co}_{3} \mathrm{O}_{4}$, $\mathrm{rGO}$ and $\mathrm{Co}_{3} \mathrm{O}_{4} / \mathrm{rGO}$ at the potential of $-0.55 \mathrm{~V}$. 

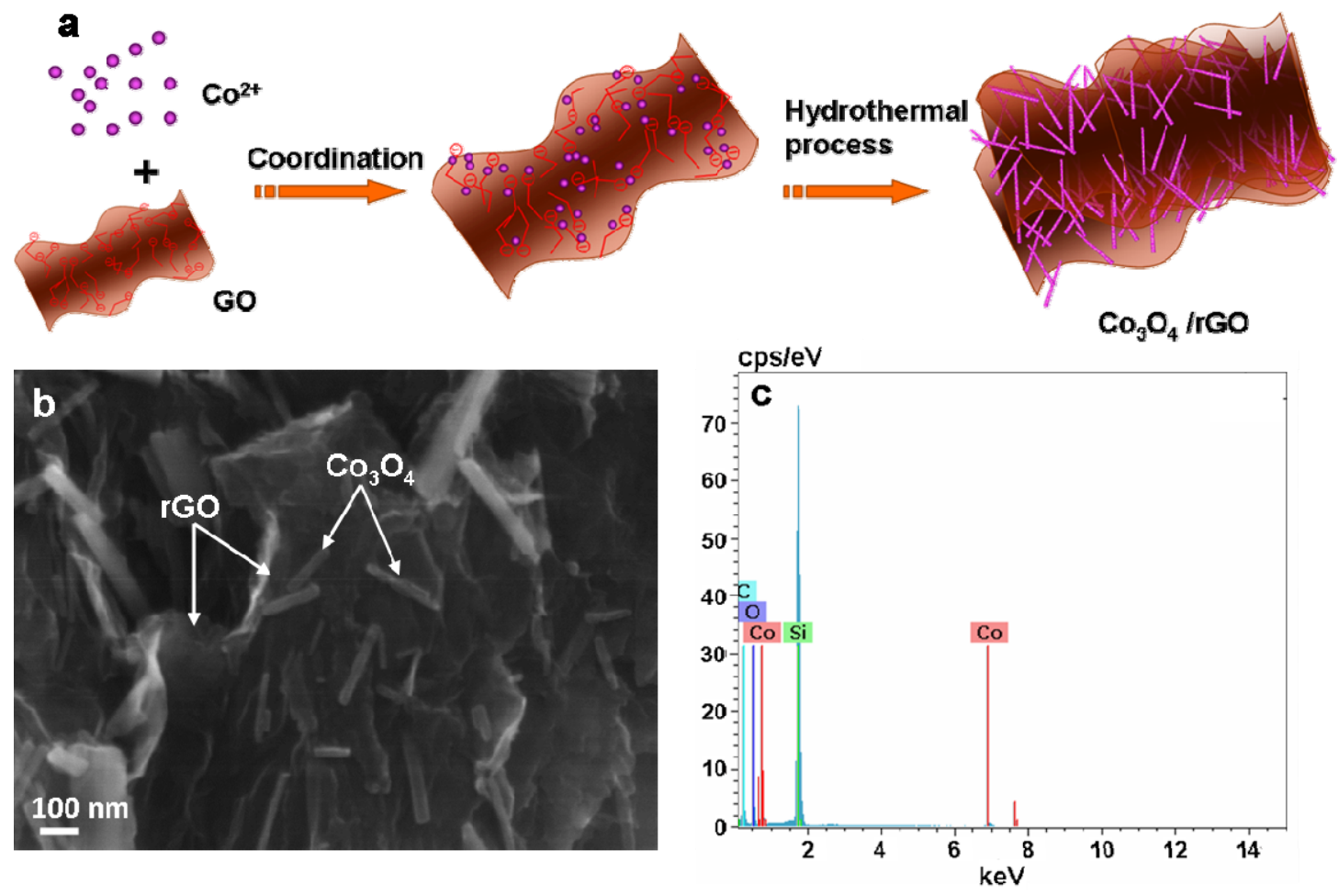

Figure 1

4 

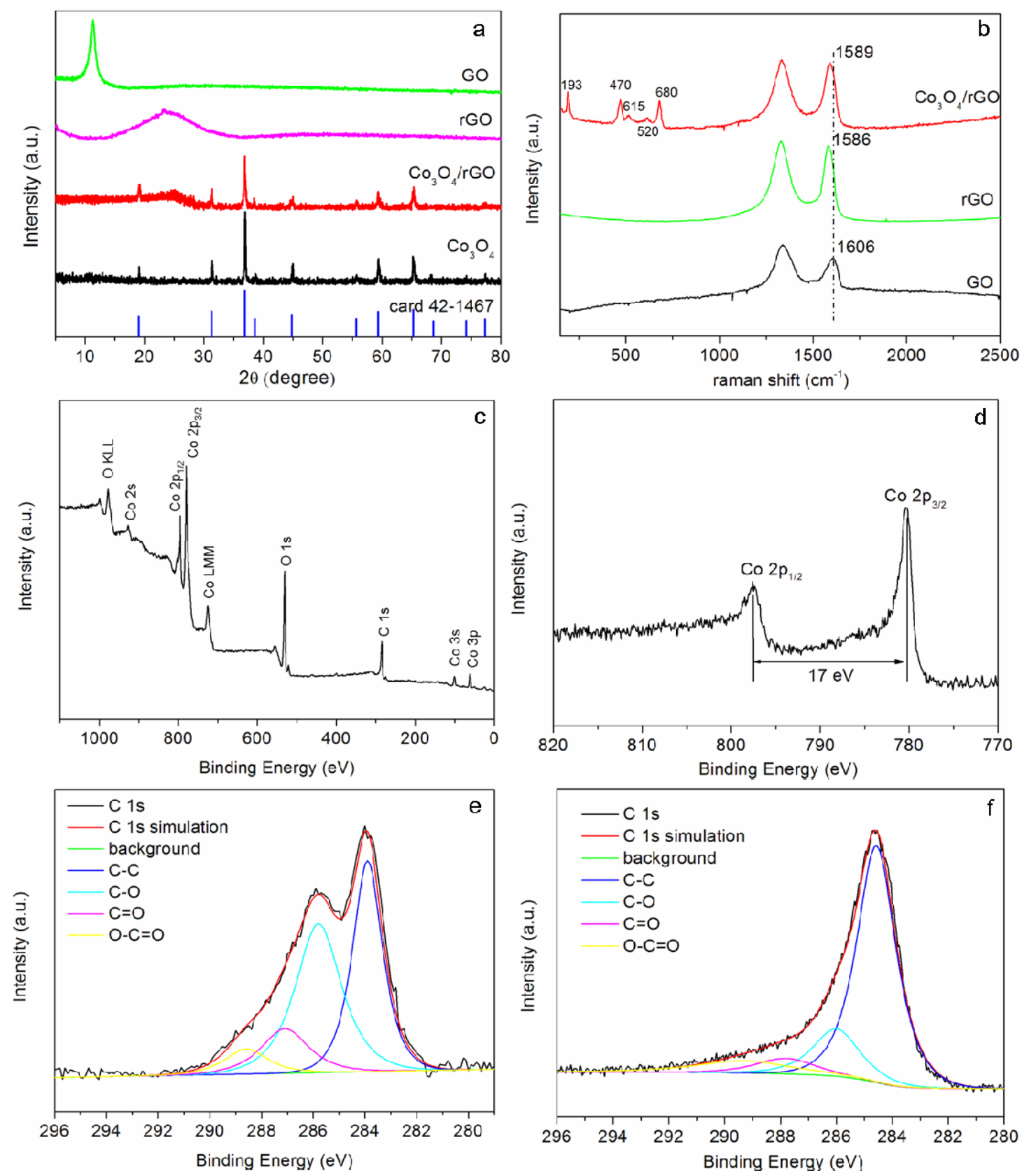

Figure 2 

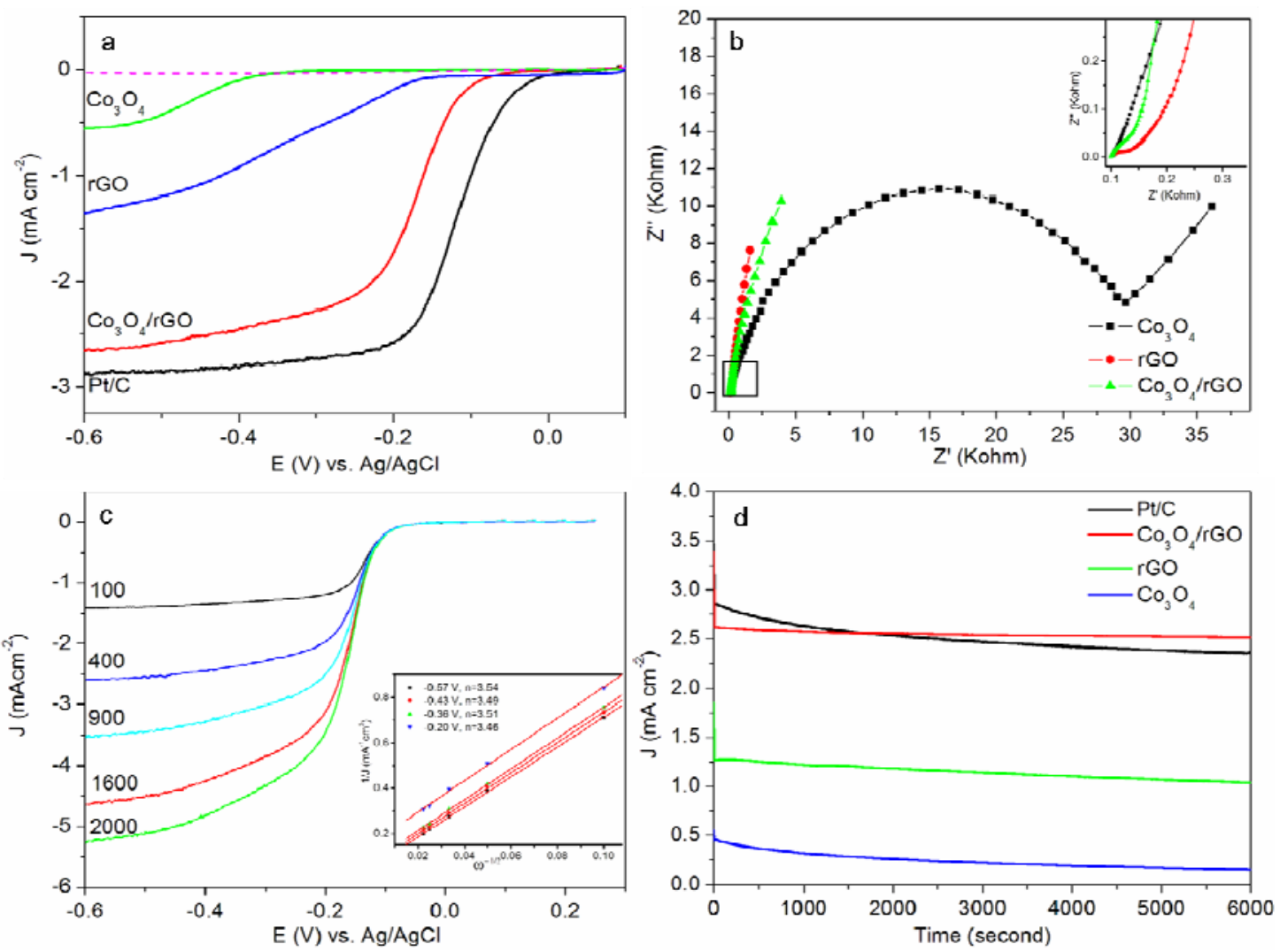

2

3

Figure 3 